An Agency Perspective on Service Triads:

Linking Operational and Financial Performance

\author{
Jie J. Zhang \\ Assistant Professor \\ University of Vermont \\ School of Business Administration \\ 55 Colchester Avenue \\ Burlington, Vermont 05405 \\ 802-656-0495 \\ jie.zhang@uvm.edu \\ Benjamin Lawrence \\ Assistant Professor \\ Cornell University \\ School of Hotel Administration \\ 246 Statler Hall \\ Ithaca, NY 14853 \\ 978-254-1669 \\ benlawrence@cornell.edu \\ Christopher Anderson \\ Associate Professor \\ Cornell University \\ School of Hotel Administration \\ 335A Statler Hall \\ Ithaca, NY 14853 \\ 607-255-8687 \\ cka9@ cornell.edu
}

Key words: Service Triads, Customer Satisfaction, Service Outsourcing, Agency Theory, Franchising

All correspondence should be addressed to Jie J. Zhang (jie.zhang@uvm.edu)

The authors would like to thank Smith Travel Research and ReviewPro for providing data. All three authors contributed equally to this work and are listed in reverse alphabetical order. 


\title{
An Agency Perspective on Service Triads: Linking Operational and Financial Performance
}

\begin{abstract}
We explore one prolific type of service triad, the franchise triad, involving three primary stakeholders: the franchisor, the franchisee and the customer. In this triad, franchisees use their affiliation with the franchisor's brand to attract customers to their local outlets. In exchange for the right of assuming the identity of the brand, the franchisee pays the franchisor royalties and retains residual profits. Applying Agency Theory, this paper examines the inherent conflict of interests between a principal (i.e., franchisor) that controls and manages brand equity as a shared resource and an agent (i.e., franchisee) that retains pricing right and profits from the identity of the brand by interacting directly with customers. We empirically isolate the effect of triad structure on outlet performance by matching two unique datasets. One set of data captures operational performance in the form of aggregated online review scores and the other financial performance including average daily hotel rate and revenue per available room. We find that franchisees charge higher prices than their corporate counterparts even when controlling for operational performance. Even though franchisees charge higher prices they maintain similar financial performance in terms of revenue per available room. These results suggest that the triad structure plays a significant role in franchisees' ability to free-ride on shared brand equity and have important managerial implications for effective outsourcing, contract design and performance evaluation for a wide range of service industries.
\end{abstract}




\section{An Agency Perspective on Service Triads: Linking Operational and Financial Performance}

\section{Introduction}

Generating USD 782 billion or 3-percent of US GDP and serving customers at over 750,000 geographically dispersed outlets; the franchise business model plays a vital role in the US economy ${ }^{1}$. Franchising involves three major stakeholders: the franchisor, the franchisee and the customer. Franchising's ubiquity, as a form of distribution, is due partially to its ability to incentivize independent local agents while affiliating them with a widely recognized brand. In this triadic relationship, franchisees (i.e., the agents) rely on the franchisor's brand to attract customers to their local outlets. In exchange for the right of assuming the brand in delivering service to customers, the franchisee pays the franchisor (i.e., the principal) royalties, typically calculated as a portion of total revenue. Customers interact with the local franchisee who is the direct service provider, yet associate their experience with the franchisor who owns the brand. For instance, McDonald's customers typically are unaware of the identities of the franchisees owning and operating the outlets.

The principal-agent relationship embodied in this triadic structure leads to potential conflict of interests. That is, the franchisor is primarily interested in building brand equity while franchisees are interested in maximizing return from owning and operating their local outlets. Since the local franchisees control both operations and pricing (Stewart and Davis 2005), franchisees may boost return by improving operations (thus gaining customers and revenue), increasing prices to inflate margins or cutting costs at the expense of operations. The latter two

\footnotetext{
${ }^{1}$ Figures obtained from The Franchise Business Economic Outlook: 2012 conducted by IHS Global Insight for the International Franchise Association.
} 
responses essentially free-ride on the principal's brand that attracts customers to the outlet (Brickley and Dark 1987; Lafontaine and Shaw 2005a).

Royalty-based contracts have been the main mechanism to incentivize operational performance in triadic relationships. For example, call center service providers can pay a 'use fee' to the buying company based on call volume while the buying company shares the cost of call center staffing to align their interests (Ren and Zhou 2008). This is similar to franchise contracts that incentivize franchisees with a share of residual profits based on revenue. However, such revenue-based incentive structures are ineffective in dealing with the brand freeriding problem inherent in the franchise triad. As long as there is no obvious negative impact on revenue, the franchisees can use their leeway in service delivery and pricing to maximize local outlet profit. Although this free-riding problem arises from the triadic structure, prior literature has largely taken a dyadic (i.e., principal-agent) (Morgan, Kaleka, and Gooner 2007; Zsidisin and Ellram 2003; Balakrishnan, Mohan, and Seshadri 2008), rather than triadic (i.e., consumerfranchisee-franchisor) perspective.

We contribute to the service triad literature by addressing several gaps. First, we introduce franchising as a service triad. We advance the understanding of such triads as the archetypical service triad where a firm (franchisor) delegates core customer-facing operations and pricing rights to third-party service providers (franchisee) and provides them with the benefits of brand equity. Although a growing body of literature has examined triadic relationships, including supply chain networks within the context of manufacturing (Choi and Wu 2009; van der Valk and van Iwaarden 2011; Choi and Wu 2008; Rossetti and Choi 2008) and service triads resulting from business process outsourcing (Niranjan and Metri 2008; Li and Choi 2009), this literature has failed to consider franchising as a prolific triadic structure. We present in Figure 1 a 
conceptualization of four fundamental types of triads that exist in the strategic outsourcing of manufacturing and service processes. Second, our unique data set allows us to empirically examine the implications of triadic relations in terms of operational performance and financial performance. Although the operations literature has begun to explore the implications of ongoing interactions within triadic relationships (Wynstra, Axelsson, and Van der Valk 2006; Van der Valk, Wynstra, and Axelsson 2009; Selviaridis and Spring 2010), empirical work examining the financial impact of service triads has been scant. This is due in part to the empirical challenges in obtaining and matching data from different stakeholders in the triad. Third, our work informs an important structural tension that has not yet been explored in the operations literature on triads. This structural tension involves brand equity as a shared resource controlled and managed by one company and a service provider that profits from the identity of the brand and controls customer-facing operations and pricing.

In this article, we address these gaps in the literature by asking the following research question: What effect do service triads, in the form of franchising, have on financial performance at the outlet level? Our model examines the potential for brand free-riding by an outsourced agent by controlling for outlet operational performance measured by aggregated customer perception. Our findings offer managerial insights on contract incentive structures and monitoring procedures related to customer-facing service triads.

The remainder of the paper is organized as follows. We first provide an integrative literature review examining the key constructs in our conceptual framework and introduce agency theory. We follow by explicating the structural differences across four types of triads and their implications for pricing and operations, taking brand affiliation into consideration. We then describe the context of our study, the US Hotel industry. Next, we develop our hypotheses and 
test these hypotheses by matching two unique datasets, ReviewPro's Global Review Index with Smith Travel Research's hotel scales and revenue data. We conclude with a discussion that highlights the theoretical contributions and managerial implications of our work along with thoughts on limitations and proposals for future work.

\section{Literature review}

A triad consisting of supplier, buyer and customer is an increasingly important unit of analysis in both manufacturing (Choi and Wu 2009; van der Valk and van Iwaarden 2011; Choi and Wu 2008; Rossetti and Choi 2008) and service (Niranjan and Metri 2008; Li and Choi 2009) settings. Triadic relationships introduce structural tensions that can impact pricing, operational performance and financial performance. Using examples from manufacturing and services, we illustrate multiple types of triads based on the structural differences in Figure 1.

\subsection{Types of Triads}

Figure 1: Strategic outsourcing of manufacturing and service processes lead to four major types of triads.

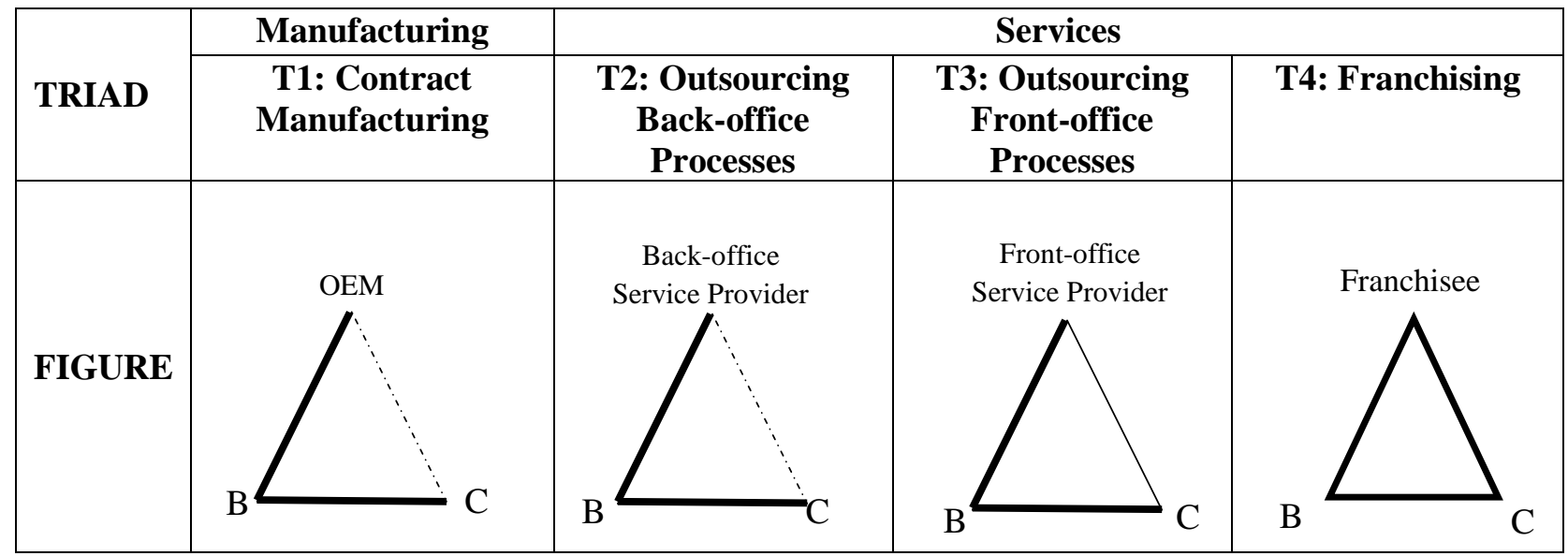

$\mathrm{B}=$ Brand Owner $/ \mathrm{C}=$ Customer

\subsubsection{T1: Contract Manufacturing}


Contract manufacturing is a common practice in the domain of tangible goods (Plambeck and Taylor 2005), which creates a triadic relationship (T1) between brand owner, OEM (original equipment manufacturer) and customer. For example, Apple designs its products but contracts OEMs to produce the goods, resulting in a triadic relationship among the brand (Apple), OEM, and customers. In this arrangement, Apple maintains tight control over the quality of the goods through design specifications, as well as pricing, marketing and servicing customers. Although brand equity may be tarnished by unethical business practices on the part of the OEM, as was the case with Apple and its manufacturer Foxconn, the link between the third-party contractor and consumer implicitly exists in the goods (represented using dotted line in the triangle). The outsourced agent in this triad has no direct contact with the end customer. T1 is not a service triad, but represents a case where control for pricing and operations resides in the brand owner.

\subsubsection{T2/T3: Outsourcing}

Business service outsourcing enabled by information technology (Apte and Mason 1995; Karmarkar 2004) results in two distinct types of triads (T2 and T3). T2 involves a brand owner outsourcing back-office operations. For example, pharmaceutical companies outsource clinical trial projects to contract research organizations to reduce the cost of clinical trials. In this type of triad, the relationship between the company and the customer remains intact because the thirdparty service provider does not interact with the end customer. Though the customer may benefit from this outsourcing arrangement, if the cost saving translates to lower price, the customer associates their experience and perception of the drug with the brand owner (i.e., the pharmaceutical company). The pharmaceutical company retains significant control over brand management and keeps its core operations of drug development and production in-house. T2 is the equivalent of $\mathrm{T} 1 \mathrm{in}$ a service setting. 
$\mathrm{T} 3$ results from outsourcing customer-facing services to a third-party service provider. This is the type of service triad investigated by most service outsourcing literature (Ren and Zhou 2008; Dean and Rainnie 2009). The triadic relationship is among the company, the third-party service provider and the customer (Niranjan and Metri 2008; Balakrishnan, Mohan, and Seshadri 2008). The third-party service provider directly interacts with the customer on behalf of the outsourcing company. During the service encounter, the customer is under the impression that the brand owner is responsible for their experience, regardless of whether they are aware of the contractual link between the company and the third-party service provider. Failure to structure a contract that incentivizes desired behavior and monitor service quality may result in behavior that damages brand equity. Given the characteristics of intangibility and heterogeneity in services, such contractual arrangements are more difficult to monitor and measure than tangible goods (Ren and Zhou 2008). The outsourced function and its performance metrics typically are well-defined, as in turnkey third-party logistic solutions.

T1, T2 and T3 share several common traits. First, the contracted agent offers cost saving through economies of scale by pooling demand for the outsourced function. Second, the contracted agent in these triads has no direct control over customer-facing pricing. Typically, the customer pays the brand owner an all-inclusive price.

\subsubsection{T4: Franchising}

The service triad (T4) we introduce involves the delegation of core customer-facing operations to an independent operator, as in the case of franchising. Franchising includes both business format franchising that involves the licensing of a business or trade style (e.g. restaurants, retail outlets, lodging) and product franchising which involves a sales relationship between a supplier and dealer (e.g. bottling companies, beer distributors, petroleum and 
automotive dealerships). These relationships involve customer-facing services that are often geographically dispersed and involve multiple agents. For example, Doctor's Associates, Inc. (DAI) is the parent company of the Subway sandwich brand but it contracts the operations of all its stores to thousands of independent franchisees that directly interact with the customer. Similarly, General Motors delegates critical distribution functions (sales and service of its vehicles) to select dealers. In both examples, high customer-contact frontline processes (Chase 1981; Metters and Vargas 2000) are outsourced while the franchisor provides support in the form of new product development and marketing. Franchisees in many systems also have some control over pricing, advertising and sales mix. Customers in such arrangements have direct interaction with the franchisee but often associate their experience with the brand owner, as what happens in $\mathrm{T} 3$.

Although some might conceptualize franchising as a special case of outsourcing because they share the common feature of direct service provider and customer interactions (represented by solid lines in the triangles), there are fundamental differences. First, the service provider has the right to adjust prices such as in promotions in franchise triads (T4), but not in business process outsourcing triads (T2/T3). Second, outsourcing adds value through demand pooling. For example, a call center is more cost efficient because it serves multiple organizations from one central location (Friedman 2002). In contrast, franchise triads aim to serve local customers more effectively by covering a dispersed geographic area while leveraging a well-known brand. This geographic dispersion is often a necessity in service based products with inseparability and perishability characteristics (Parasuraman, Zeithaml, and Berry 1985). In addition, limitations related to distribution in certain market segments necessitate the widespread dispersion of individual outlets to service local customers. Although technology may result in 
disintermediation of such outlets shifting to centralized distribution that is more cost effective (e.g. the Blockbuster franchise model failure with the introduction of Netflix and streaming video), most service based products require local presence. Third, the outsourced function in T3 typically is a well-defined subset of the total functions that the company provides its customers with, while the outsourced function in T4 is the core value proposition. In short, the franchisee's pricing flexibility, the geographic dispersion of local outlets and the delegation of core functions are key factors to consider in incentivizing and monitoring franchise service triads.

\subsection{Triads and the Principal Agent Problem}

Research examining interorganizational relationships in the operations literature (see Morgan, Kaleka, and Gooner 2007), and marketing channels literature (see Bergen, Dutta, and Walker Jr 1992) have used agency theory to explore the behavior of organizational partners. The primary focus of agency theory has been on the problems arising between principals and agents when each party works in their own self-interest and bounded rationality leads to an inability to monitor each party's behavior. Models of interorganizational behavior based on agency theory in the operations literature have primarily focused on one unit of study, the dyadic relationship between channel partners (see Handley and Benton 2012). Recent work has highlighted the potential of applying agency theory within the context of triadic relations in supply chains (Fayezi, O’Loughlin, and Zutshi 2012).

Research applying agency theory in a distribution setting examines two main relationship domains, vertical and horizontal agency (Combs, Michael, and Castrogiovanni 2004). Vertical agency involves issues related to a firm and the managers of its outlets. If unmonitored, vertical agency predicts that outlet managers will reduce their effort (i.e. shirk) because their self-interest is not tied directly to the success of the outlet. This vertical agency problem can be solved 
through a combination of incentives and monitoring. Franchising is one contractual relationship that partially solves vertical agency issues as franchisees as residual claimants directly benefit from increased effort at the unit level. However, as franchisees are interested in profitability at the unit level and must pay royalties on total revenues, there is incentive to reduce costs even at expense of lowering system wide brand equity. The prevailing assumption of opportunism, the cornerstone of agency theoretic arguments, presupposes that channel partners, as self-interested actors, will take advantage of the brand to further their own wealth at the expense of other stakeholders including fellow channel members (Lafontaine and Shaw 2005a). Such behavior involves horizontal agency, or the potential for franchisees to free-ride on the brand.

In this paper we make a distinction among channel partners based on two distinct management functions, the management of the brand and its value and the management of frontline service operations. In the case of a franchise triad, the owner of the brand (franchisor) and the third party performing the outsourced service (franchisee) have different goals. The franchisee accrues the benefit of being part of a branded chain but is motivated to maximize individual outlet performance rather than total chain performance. The nonreciprocal structure regarding a shared brand resource can create positive spillover (Brickley and Dark 1987) allowing franchisees to free-ride on the franchisor's brand. Such free-riding behavior can include cutting corners (thus under-delivering quality and customer value) or overcharging customers, such that the franchisee profits from the brand without bearing the proportional share of costs.

Both vertical agency and horizontal agency issues may influence the pricing of products at individual outlets. However, they predict two different patterns of results related to operational performance. If franchise contracts properly incentivize outlet franchisees, thus solving the vertical agency issue, then franchisees should deliver higher levels of operational performance 
than less motivated corporate employees. On the other hand, horizontal agency should result in brand free-riding encouraging outlet franchisees to overprice or under-deliver resulting in lower levels of operational performance for the same level of payment. If we examine pricing at the outlet level and control for operational performance we should be able to examine the potential for franchisees to overprice.

\section{Theory and hypotheses}

The goal of this paper is to investigate the effect of triadic structure on financial performance in the context of franchising operations. We are particularly interested in two financial performance indicators: pricing and revenue. We present our conceptual model that explains the relationship among the key constructs: operational performance, brand affiliation, triad structure, and financial performance in Figure 2.

Figure 2: Conceptual Model and Hypotheses

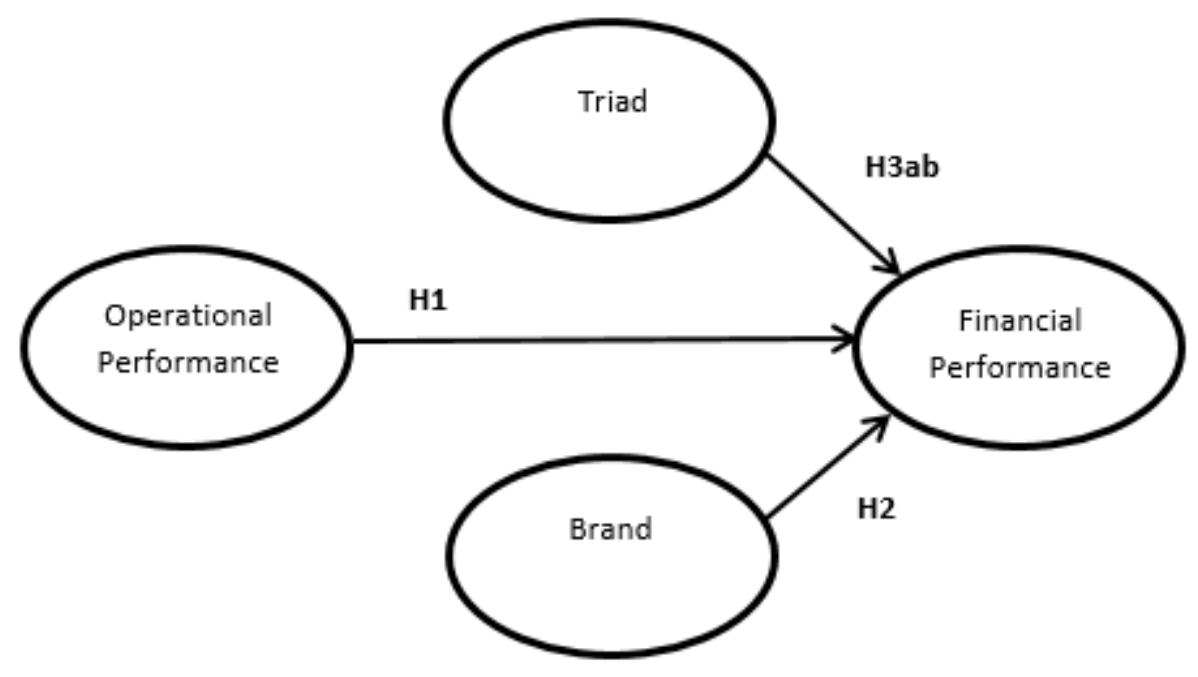

Because franchise triads by default have a brand affiliation, we need to compare the pricing and revenue performance of three types of operating units: unbranded dyad, dyad with brand and triad (captured by the two categorical variables Triad and Brand). For example, an independent 
fast food restaurant is a dyad with no brand affiliation; a McDonald's corporate owned and operated outlet is a dyad with a shared resource of brand equity; and a McDonald's franchised outlet is a triad with a shared resource of brand equity. Comparisons among these three types of operating units will isolate the effect of triadic structure. Isolating the potential brand effects on pricing and revenue are important given our goal of examining performance enhancement (or reduction) from the triad structures inherent in franchising, thus offering insights on contract incentive design and monitoring for service triads. Our conceptual model allows for comparison between three types of organizational forms: dyad, dyad with brand, and triad (with brand).

\subsection{Effect of Operational Performance on Financial Performance}

Outlets with high levels of operational performance should benefit financially as demand should increase pricing power. Numerous studies have linked customer perception of operational performance in the form of online customer reviews, to increased pricing power (Melnik and Alm 2002a; Houser and Wooders 2006; Standifird 2001) and performance (Luo 2009; Trusov, Bucklin, and Pauwels 2009; Villanueva, Yoo, and Hanssens 2008). Sellers with high consumer ratings are also more likely to sell their products in the context of auctions (Resnick and Zeckhauser 2002) and attract more bidders and higher prices for their items (Melnik and Alm 2002b; Lucking-Reiley et al. 2007; Resnick et al. 2006). Positive consumer reviews have also been shown to impact aggregate sales (Godes and Mayzlin 2004; Chevalier and Mayzlin 2006; Ghose, Ipeirotis, and Li 2010; Berger, Sorensen, and Rasmussen 2010) and pricing power (Tirunillai and Tellis 2012; Kuksov and Xie 2010). One may argue that performance differences could be a result of varying operational effectiveness as proposed in a vertical agency argument. That is, better service leads to higher perceived value and 
subsequently higher pricing power and revenue. By including operational performance in the model, we are able to single out the brand and triad structure effects. We therefore propose:

H1. There is a positive main effect of operational performance on financial performance.

\subsection{The Effect of Brand Affiliation on Financial Performance}

An extensive body of work in marketing supports the claim that brands increase perceptions of quality, value and willingness to pay (Aaker 1991; Dodds, Monroe, and Grewal 1991; Rao and Monroe 1989). Brands also help to reduce uncertainty and act as a guarantee of performance (Klein and Leffler 1981; Milgrom and Roberts 1986). The effect of brands and performance on pricing are particularly impactful in the service industry given the perceived risk and uncertainty associated with purchasing an intangible product (Murray 1991; Murray and Schlacter 1990). By including brand affiliation in our model, we are able to isolate triad structure effects from brand effects. We therefore propose:

H2. There is a positive main effect of brand affiliation on financial performance.

\subsection{The Effect of Triad Structure on Financial Performance}

After controlling for brand effects and operational performance we can isolate the effect that a triad structure has on performance, including the price (i.e., cost paid by the customer) and revenue performance. There are two theoretical arguments that support the claim that a service provider in a triad will charge its customers higher prices. First, triads may incur higher coordination costs. Triad structures require more complex contractual arrangements and thus may be more costly to maintain and enforce, however productivity gains due to specialized knowledge and incentives may offset these costs (Darr, Argote, and Epple 1995). Double marginalization, where each party optimizes according to its own objectives, also points to 
higher price (Tirole 1988). However, this would also result in lower demand thus resulting in lower overall revenue due to deadweight loss for franchised outlets.

The second theoretical argument in support of higher prices involves the potential of thirdparty service providers to free-ride on the brand as argued in the horizontal agency discussed earlier. In the case of a triad, the owners of the brand (i.e. franchisor) and the service provider performing the service (i.e. franchisee) have different goals. The franchisee accrues the benefit of being part of a branded chain but is motivated to maximize individual property performance rather than total chain performance. In addition, the franchisee is not fully accountable for its operation's impact on the shared resource of brand equity. That is, the nonreciprocal structure regarding the brand can create positive spillover (Brickley and Dark 1987) allowing franchisees to free-ride on the franchisor's brand. Such free-riding is a problem that has been commonly acknowledged in the literature (Lafontaine and Shaw 2005b; Brickley and Dark 1987; Mathewson and Winter 1985; Shane 1998) that cannot be completely mitigated through contract design (Freedman and Kosová 2012; Quinn 1999; Michael 2002). Such free-riding behavior can include providing less service or overcharging customers, such that the franchisee benefits from the brand without bearing the proportional share of costs. Unlike triads that separate brand management and customer service functions, dyads, as represented by chain managed properties and independents, have no incentive to free-ride given that brand management functions and the service itself are fulfilled by the same party. Both chain managed chains and independents bear the full costs of lower operational performance and this should be reflected in their pricing. We therefore propose:

H3a. There is a positive main effect of triad on price. 
Although we expect that after controlling for brand effects franchised outlets (triad) will maintain higher prices than either corporate owned or independent outlets (dyads) we do not expect that overall outlet performance measured by revenue will differ. Research has shown that third-party service providers can be incentivized to increase effort by retaining residual profits and in return pay a fixed proportion of their revenues to the outsourcing company (Krueger 1991). These revenue-based incentives however should theoretically encourage the third-party service provider to charge higher prices because of the cost structure. For example, the hotel industry uses revenue per available room $\left(\operatorname{RevPAR}^{i}\right)$ to measure the overall financial performance by taking both price $\left(\mathrm{ADR}^{\mathrm{iv}}\right)$ and occupancy into consideration. To achieve the same RevPAR, the franchisee would prefer higher margin at the expense of occupancy versus keeping price low and increasing occupancy. The reason is that higher occupancy rates incur proportionally higher costs (royalty payment plus variable costs) than raising price and increasing margin. Therefore, we don't expect that the triad structure will affect revenue as franchisees will charge higher prices but will also reduce occupancy. We therefore propose:

H3b. There is no main effect of triad on revenue.

When $\mathrm{H} 3 \mathrm{a}$ and $\mathrm{H} 3 \mathrm{~b}$ are both supported, it provides evidence of brand free-riding and exposes the weakness of revenue-based incentives.

\section{Empirical methodology}

We situate our empirical investigation in the US hotel industry where dyads and triads coexist. This industry is representative of many settings where triadic relationships are critical to the experience and performance of parties in the triad. For example, in the automobile supply chain, the automakers contract local dealerships to provide customer-facing services ranging from sales support to price negotiation to after-sales maintenance. The dealerships rely on their 
affiliation with automakers' brands to attract customers to their local outlets; while customer experience and perception of the brand depends on their interactions with the dealership throughout price negotiation and auto care.

In the US hotel industry nearly half of the properties are affiliated with a national chain (Census Bureau 2010). Among the brand affiliated hotels, some are owned and operated by hotel chains, while others are branded under national chains but owned and managed by institutional investors (including real estate trusts (REITs), real estate investment funds and private equity firms) (deRoos 2010). As a result, three main categories of hotels exist independent unbranded properties, franchise units, and chain owned and branded unitsii. Figure 3 classifies these three broad categories along the dimensions of organizational structure and shared brand affiliation.

Figure 3: Classification of hotel properties by brand affiliation and dyad/triad structures

\begin{tabular}{c|c|c|}
\multicolumn{2}{c}{} & \multicolumn{2}{c}{ Brand Affiliation } \\
\multicolumn{1}{c|}{ (Shared Resource of Brand Equity) } \\
YES
\end{tabular}

We define the organizational form as dyadic when the party that provides the service and the brand, as perceived by the customer, belongs to the same organization. An independent property and its customers constitute a dyad because the property management is solely responsible for delivering the service experience and the brand equity accrues to the same organization. Similarly, a chain owned and managed property is also in a dyadic relationship with the 
customer. The difference is that the brand is a shared resource among the properties with the same affiliation that is recognized by customers. As a result, all these properties contribute to the brand equity they are affiliated with and in return benefit from the brand equity improvement. By contrast, a franchise property becomes a service triad where customers interact with the franchisee during service delivery, but associate their service experience with the brand. Figure 4 illustrates the relationship among the service triad participants involved in franchise properties. The nonreciprocal structure regarding shared brand resource sets franchise properties apart from independent and chain managed properties.

Figure 4: A service triad in US hotel industry: Managerial decisions of each outlet are distributed across multiple parties interacting with customers regarding brand and service management.

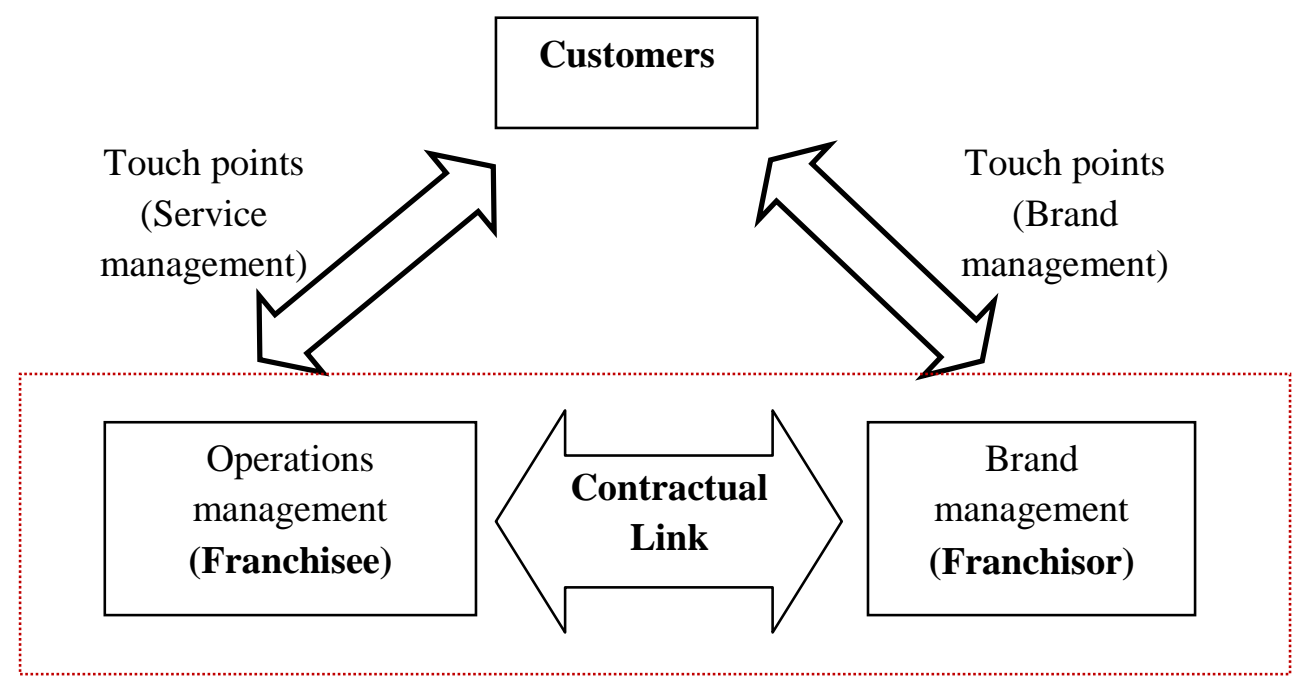

Using competitive set ${ }^{\mathrm{iii}}$ adjusted Average Daily Rate (ADR) index ${ }^{\mathrm{iv}}$ and RevPAR index as performance indicators, we compare service triads and dyads in the US hotel industry. Our keen interest is on the pricing and revenue implications of the triad structure, controlling for variations in operations, brand affiliation, and other contextual variables. 


\subsection{Data description}

We combine two data sources, one on hotel performance and the other on customer perception data at the property level, to test our hypotheses. Performance data are monthly revenue, demand, and supply data from Smith Travel Research (STR) for 3 years (January 2010 through December 2012). We have these data for 15 major North American cities ${ }^{2}$.

We use ReviewPro's Global Review Index (GRI), an online reputation index, as our measurement of operational performance. Recent operations management literature on operational performance metrics (for example, Melnyk, Stewart, and Swink 2004; Stank, Goldsby, and Vickery 1999) has argued for the use of customer perceptions of provider performance as a metric that captures how the operation delivers value to its targeted customers. ReviewPro aggregates hundreds of millions of social media mentions, in over 35 languages, from online travel agencies, review websites and social media platforms. The GRI is an aggregate online reputation score for an individual hotel. It is based on scores given by consumers at major online review sites and online travel agencies and evaluates a hotel across various dimensions including cleanliness, decoration, food and drink, reception, room, and service. The GRI is calculated by analyzing quantitative scores on these sites, using a proprietary algorithm. ${ }^{v}$ Therefore, the GRI index used in our study is an adequate and appropriate measure of the operational performance of the service provider. The ReviewPro's Global Review Index data we obtained however do not cover economy outlets. We discuss this limitation in the conclusion section. After matching of the two data sets we have a sample of 33,354 matched monthly observations across 1072 hotels.

\subsection{Operational and financial performance variables}

\footnotetext{
${ }^{2}$ Austin, Charlotte, Dallas, Denver, Los Angeles, Miami, New Orleans, New York, Phoenix, Portland, San Diego, San Francisco, Seattle, Toronto, Vancouver.
} 
Table 1 summarizes means and standard deviations for the three performance measures across chain scales $^{3}$ as defined by STR. ADRs decrease with decreasing chain scale, with occupancies also decreasing with decreasing chain scale and RevPAR (the product of ADR and Occupancy) decreasing with decreasing chain scale as price changes (across chain scales) dwarf occupancy changes. Our operational performance measure, GRI, also decreases with decreasing chain scale. The distribution of our sample across the chain scales is summarized in Table 2.

Table 1: Operational and Financial Performance metrics by STR chain scale classification

\begin{tabular}{|c|c|c|c|c|c|c|}
\hline & & \multicolumn{5}{|c|}{ Chain Scale } \\
\hline & & Luxury & $\begin{array}{l}\text { Upper } \\
\text { Upscale }\end{array}$ & Upscale & $\begin{array}{l}\text { Upper } \\
\text { Midscale }\end{array}$ & Midscale \\
\hline \multirow[t]{2}{*}{$\operatorname{ADR}(\$)$} & Average & 277.90 & 163.68 & 127.89 & 112.75 & 78.71 \\
\hline & Std. Deviation & 159.87 & 57.67 & 50.20 & 45.69 & 32.98 \\
\hline \multirow[t]{2}{*}{ RevPAR (\$) } & Average & 207.02 & 123.02 & 98.74 & 83.00 & 53.11 \\
\hline & Std. Deviation & 123.67 & 58.36 & 54.26 & 50.72 & 36.01 \\
\hline \multirow{2}{*}{$\begin{array}{l}\text { Operational } \\
\text { Performance } \\
(\text { GRI) }\end{array}$} & Average & 0.86 & 0.82 & 0.81 & 0.79 & 0.75 \\
\hline & Std. Deviation & 0.06 & 0.06 & 0.07 & 0.08 & 0.10 \\
\hline
\end{tabular}

Table 2: Sample makeup (\%) by chain scale.

\begin{tabular}{lrrrrr}
\hline \multicolumn{1}{c}{ City } & Luxury & $\begin{array}{c}\text { Scale } \\
\text { Upper } \\
\text { Upscale }\end{array}$ & Upscale & $\begin{array}{c}\text { Upper } \\
\text { Midscale }\end{array}$ & Midscale \\
\hline Austin & $6.2 \%$ & $21.5 \%$ & $36.9 \%$ & $16.9 \%$ & $18.5 \%$ \\
Charlotte & $5.1 \%$ & $22.4 \%$ & $41.4 \%$ & $19.0 \%$ & $12.1 \%$ \\
Dallas & $11.1 \%$ & $38.9 \%$ & $25.0 \%$ & $12.5 \%$ & $12.5 \%$ \\
Denver & $13.6 \%$ & $19.9 \%$ & $27.3 \%$ & $24.2 \%$ & $15.0 \%$
\end{tabular}

\footnotetext{
${ }^{3}$ Chain scale segments are a method by STR that groups hotels into different comfort levels, based on the actual average room rates.
} 


\begin{tabular}{lrrrrr} 
Los Angeles & $17.0 \%$ & $44.7 \%$ & $17.0 \%$ & $19.2 \%$ & $2.1 \%$ \\
Miami & $27.9 \%$ & $22.1 \%$ & $38.2 \%$ & $8.9 \%$ & $2.9 \%$ \\
New Orleans & $21.7 \%$ & $26.1 \%$ & $21.7 \%$ & $24.6 \%$ & $5.9 \%$ \\
New York & $23.6 \%$ & $25.3 \%$ & $30.3 \%$ & $17.4 \%$ & $3.4 \%$ \\
Phoenix & $5.6 \%$ & $19.7 \%$ & $29.6 \%$ & $29.6 \%$ & $15.5 \%$ \\
Portland & $4.8 \%$ & $28.5 \%$ & $28.6 \%$ & $20.6 \%$ & $17.5 \%$ \\
San Diego & $6.3 \%$ & $34.4 \%$ & $23.4 \%$ & $20.8 \%$ & $15.1 \%$ \\
San Francisco & $17.0 \%$ & $51.2 \%$ & $13.8 \%$ & $7.5 \%$ & $10.5 \%$ \\
Seattle & $11.9 \%$ & $26.3 \%$ & $27.6 \%$ & $18.4 \%$ & $15.8 \%$ \\
Toronto & $18.9 \%$ & $24.5 \%$ & $26.4 \%$ & $24.5 \%$ & $5.7 \%$ \\
Vancouver & $23.8 \%$ & $23.8 \%$ & $19.0 \%$ & $23.8 \%$ & $9.6 \%$ \\
\hline All & $15.2 \%$ & $28.7 \%$ & $27.5 \%$ & $18.9 \%$ & $9.7 \%$ \\
\hline
\end{tabular}

We have this performance data at the property and competitive set level, where the competitive set is a list of hotels (typically 5-10) specified by the hotel property as its major competitors. As these hotels operate in a competitive market we use relative measures versus absolute measures - specifically we create ADR, RevPAR and GRI Indices - e.g. an outlet's RevPAR divided by the average RevPAR of its competitive set. As these indices take into account performance related to competitive sets they help adjust for outlet specific effects when testing out hypotheses. Table 3 summarizes the index averages across organizational structures and brand makeup. While the averages show distinct patterns, with branded Dyads always the highest followed by branded Triads then unbranded Dyads, none of these differences are statistically significant.

Table 3: Index averages by organizational form

\begin{tabular}{lccc}
\hline & & \multicolumn{2}{c}{ Branded } \\
& & Yes & No \\
\hline RevPAR Index & Triad & 1.006 & \\
& Dyad & 1.059 & 0.953 \\
\cline { 2 - 4 } ADR Index & Triad & 0.994 & \\
& Dyad & 1.045 & 0.970 \\
\cline { 2 - 4 } Operational & Triad & 0.998 & \\
Performance Index & Dyad & 1.012 & 0.989 \\
\hline
\end{tabular}




\section{Results}

Using the unique matched data set we are able to compare three organizational forms (dyad, dyad with brand, and triad), thus isolating the effects of brand affiliation and triad structure on both price and performance through a series of linear regressions for the two performance indicators. For ease of presentation we continue to refer to the two performance indications as ADR and RevPAR even though they are indices versus absolute values. Given the right skewed nature of our data, owing to the use of indices (index never $<0$ ), we transform all our continuous variables by taking natural logarithms. As a result of these transforms, regression coefficients of continuous variables are elasticity estimates and represent percentage changes in the nontransformed dependent variables given a percentage change in the non-transformed independent. In our regressions, we also control for hotel chain scale (star level) using indicator variables. We also account for Brand and Triad effects using dummy variables. As a result of using a log transformed dependent variable and categorical (dummy) independents, the impact of a (dummy) variable upon the non-transformed dependent is $\mathrm{e}^{\text {coefficient }}$. Owing to the time series nature of our panel data we formulate a hierarchical linear model with repeated measures. Specifically we use a two way random effects model to account for both firm specific (1072 firms) and time effects (36 time series observations per firm) using PROC TSCSREG in SAS 9.2 to perform this autocorrected regression.

Table 4 summarizes model coefficients for the two performance indicators; we use the same independents across both dependents with the exception of the inclusion of occupancy (index) for ADR owing to firms adjusting prices relative to demand.

Table 4: Financial performance dependent variable regression results

\begin{tabular}{lcc}
\hline & ADR & RevPAR \\
\hline Constant & -0.01027 & 0.047406
\end{tabular}


Operational performance

Triad

Brand

Luxury

Upper UpScale

UpScale

Upper MidScale

Size

Occupancy

Variance Components

Cross Sections

Time Series

Errors

Interclass Correlation Coefficients
$(0.0329) \quad(0.0464)$

$0.101473 * * \quad 0.307516 * *$

$(0.00912) \quad(0.0164)$

$0.087359 * * \quad 0.02482$

(0.0123) (0.0154)

$0.10568 * * \quad 0.141696 * *$

(0.0122) (0.0173)

$0.186697 * * \quad 0.211103 * *$

(0.0182) (0.0258)

$0.119766 * * \quad 0.153316 * *$

(0.0165) (0.0233)

$0.09153 * * \quad 0.123358 * *$

$(0.0155) \quad(0.0219)$

$0.054036 * * \quad 0.048569 *$

$(0.0163) \quad(0.0230)$

$-0.0321 * * \quad-0.0472 * *$

(0.00636) (0.003114)

$0.25392 * *$

(0.00272)

\begin{tabular}{cr}
0.017575 & 0.034841 \\
0.000017 & 0.000038 \\
0.004743 & 0.015644 \\
0.7874 & 0.6901 \\
\hline
\end{tabular}

** $\mathrm{P}<0.0001, * \mathrm{P}<0.05$ 
We control for chain scale with the chain scale indicator coefficients showing decreasing ADRs by decreasing chain scale (midscale hotels being the reference chain scale). The Size variable, where Size is the natural log of the number of rooms, controls for hotel size. The model results strongly support hypotheses 1 through $3 a$ and $3 b$.

We find support for our hypothesized main effects (H1, H2 and H3). In Table 4 ADR column, the 0.101 coefficient estimate $(\mathrm{p}<0.0001)$ for GRI indicates that a 1 -percent increase in operational performance is correlated with a 0.101-percent increase in ADR. We found a similar effect in terms of RevPAR where a 1-percent increase in GRI is correlated with a 0.308-percent increase in RevPAR. We also find support for our second hypothesis that branded outlets have higher ADR and RevPAR. The ADR ratio between the branded outlets and their non-branded counterparts is $1.115\left(\mathrm{e}^{0.106}=1.115\right)$ and RevPAR ratio $1.152\left(\mathrm{e}^{0.141696}=1.152\right)$. There is evidence supporting H3. Table 4 shows that the Triad indicator variable has a coefficient estimate of $0.087(\mathrm{p}<0.0001)$ for the main effect of the triad structure in the model with ADR as the dependent variable, which means that triads have ADRs 1.091 times those of comparable dyads $\left(\mathrm{e}^{0.087}=1.091\right.$ ), after controlling for both operational performance and brand effects. As proposed we find no main effect of triad structure on $\operatorname{RevPAR}(\mathrm{p}=0.106)$.

Our results reject the argument that higher prices are the only result of higher operational performance as argued by vertical agency. In other words, for the same level of operational performance, prices charged by service providers in a triad are higher than those charged by outlets in a dyadic relationship. Franchisees charge higher prices than their independent or corporate counterparts. As we hold operational performance constant, these price increases 
cannot be attributed to higher levels of performance on the part of customers at franchised properties but consistent with free-riding on the brand as argued by horizontal agency.

The null effect concerning the relationship between triad and revenue further corroborates our claim that franchisees have incentive to free-ride on the brand under current revenue-based performance measures because they can free-ride without impacting overall performance at the outlet level. One possible explanation for this is that franchisees are able to use the brand to charge higher prices to their customers and not suffer disproportionality by incurring lower occupancy. This finding highlights the limitation of revenue based performance measures and the associated undesirable franchisee behavior at the outlet level. That is, when the third-party service provider controls pricing and the geographic dispersion limits effective monitoring as in a franchise service triad, the structural tensions result in free-riding on the brand by the franchisee.

\section{Conclusion}

Our data demonstrate that franchisee outlets charge higher prices than brand owned and operated ones but show similar revenue for the same level of operational performance. This suggests that the revenue based performance royalty in the franchise contract is not sufficient to deter free-riding. Though these higher prices may be the consequence of the organizational and incentive structures in place they do represent a form of brand freeriding, albeit one that may not be intentional on the part of the service provider. These findings are generalizable to other service triads that are characterized by variable pricing, shared brand affiliation and delegation of customer-facing functions. In this section we discuss the theoretical contributions and managerial implications of this study, then offer our thoughts on limitations and future research topics. 


\subsection{Theoretical Contributions}

We contribute to the operations and supply chain management literature by advancing knowledge on key issues within triadic structure: pricing, brand equity and operational performance.

\subsubsection{Variable Pricing in Service Triads}

In instances of downstream vertical integration or when contractual constraints related to pricing limit third-party providers or resellers, the corporation maintains pricing control. Other forms of distribution however allow for greater freedom regarding pricing at the local outlet. Franchising is one triad structure that allows service providers to set their own prices (Stewart and Davis 2005). Diverse sets of service industries including food service (e.g., McDonalds), commercial cleaning (e.g., Jani-King), hair services (e.g., Great Clips), tax preparation (e.g., H\&R Block) and convenience stores (e.g., 7-Eleven) routinely run promotions such as bundling and discounting to maximize individual outlet profitability. In addition, information technology enables the application of dynamic pricing beyond the traditional examples of airlines and hotels. For example, Broadway shows have adopted variable pricing to drive financial performance (Healy 2014).

A better understanding of the implications of triad structure on pricing in these service settings has far reaching impact. Prior literature on triads has largely focused on T1, T2 and T3 types (see Table 1) excluding the contracted agent from the customer-facing pricing decision. This study is the first, to our knowledge, to examine customer-facing pricing by a third-party contracted agent in triads. Our findings are consistent with franchising literature that has demonstrated greater price dispersion in quick service franchising outlets relative to corporate owned businesses (Lafontaine 1999).

\subsubsection{Brand Equity}


Like Li and Choi (2009), we focus on the potential downside of the triad structure. Specifically, we examine the potential negative effects outsourcing may have on a critical and often ignored asset of the firm, brand equity. Prior research has demonstrated that chains with more valuable brand names are more vulnerable to free-riding (Michael 2000). One reason that companies including Chipotle and Starbucks have given for developing corporate rather than franchised outlets has been protecting brand equity. The choice, to operate as a dyad or triad, may depend on a brand's value in the marketplace. Though we do not explicitly measure brand equity, our work supports such an argument given that after controlling for operational performance franchised outlets charge higher prices coupled with no differences in revenue performance. Therefore studies that focus on overall performance of the service provider without controlling for operational performance metrics are likely to miss the potential negative influence such arrangements might have on brand equity.

\subsubsection{Operational Performance}

We also add to the literature examining channel relationships and agency theory (see Fayezi, O'Loughlin, and Zutshi 2012 for review of agency theory in supply chain management) by examining the linkages between operational and financial performance. Work examining triads extends the principal-agent relationship past the usual principal-agent dyad to include other potential nodes, one of which is the customer. Researchers have argued that franchisees, as part of a branded chain, could free-ride on the brand and therefore lower quality and raise price, thus leading to lower levels of operational performance (Caves and Murphy 1976; Lafontaine and Shaw 2005). Though work examining these effects has looked at outcome measures including RevPAR and ADR as a proxy of operational performance, our data, that controls for operational 
performance while measuring financial performance, supports this agency argument related to free-riding.

\subsection{Managerial Implications}

Our findings have several important managerial implications regarding incentive structures and contract design. We caution firms that are outsourcing frontline processes particularly to reexamine how well the service provider incentives align with building brand equity. Understanding how to align triad partners, including franchisees and their corporate counterparts, through alternative mechanisms such as brand identification holds promise. Such identification is clearly present in a system like Chick-fil-A that selects operators with similar values to the founder and intensively socializes them to internalize the brand and closely identify with franchisor management (Reichheld 2001; Berry 2000). Much like relational norms facilitate the investment in firm specific assets (Heide and John 1992) or control opportunism (Brown, Dev, and Lee 2000) such identification between franchisee and franchisor may have salutary benefits including pro social behavior (O’Reilly III and Chatman 1986) and loyalty (Adler and Adler 1988). The degree to which service provider identification with the corporate brand owner might serve to align interests and thus impact a service provider's behavior are interesting research questions for future work.

Our findings also provide guidance to brand managers looking to protect and build brand equity when outsourcing customer service. Specifically, close monitoring of the relationship between operational performance and pricing can offer clues to free-riding behavior. Monitoring operational performance by utilizing experts in the form of corporate audits or third party secret shoppers is expensive and often occurs infrequently. Utilizing crowd sourced online reviews and other social media metrics to monitor customer perception of operational performance at the 
outlet level may be one low cost solution. In addition to their low costs, online reviews have other potential benefits including their breadth and depth of coverage (Zhu and Zhang 2010; Luca 2011) and perceived trustworthiness (Bickart and Schindler 2001). Developing incentives for customers to respond to online reviews is one mechanism for improved monitoring. This may be especially important in locations that have low repeat business (airports, highway stops) or those that have superior locations and thus higher opportunities for brand free-riding. Managers must assess the impact of service outsourcing for different types of outlets or operators.

\subsection{Limitations and future research}

Several of the variables in our model present limitations. Even though we index performance measures to competitive sets, we acknowledge that there may be factors that influence an operating unit's financial performance that we did not capture in the model. We also use a proprietary algorithm, ReviewPro's aggregate review score, in our analysis. ReviewPro's aggregate review scores are used by their clients for benchmarking given hotels or hotel chains, to compare properties in a singular chain and to track operational performance over time. Given that this review score is used by over 10,000 hotels globally we feel it has considerable external validity. One limitation of using the ReviewPro's aggregate review score is that the data we obtained do not cover economy outlets. Our sample therefore consists of all chain scales except for economy. It is worth noting that economy outlets are predominantly franchised with very few corporate owned and operated outlets. Even with the exclusion of economy properties, we feel that the benefits of using the ReviewPro data outweigh its disadvantages.

Our dataset also suffers from selection bias given that hotel properties must opt in to the STR dataset. Pairing this up with customer satisfaction data provided by ReviewPro further reduces the dataset. The resulted cross-sectional sample consists of North American hotels, in 15 cities, 
in the midscale and higher segments. This limitation affects the representativeness of our sample and the inferences we can make from the results. This shows the trade-offs that are faced by researchers using paired data from company sources. Given the difficulty in obtaining and matching this type of data, we feel that any potential bias must be weighed against the potential contribution of the work. Although we do not have any reason to believe that such selection bias would alter our results, replication studies at a different time, in other countries and locales, and in other market segments provide fruitful avenues for future research .

Our study examined one major type of service triad, that of franchising, in the empirical context of the hotel industry. As we have argued, franchising is a highly prevalent form of distribution that exists in a broad spectrum of industries. Certain industry characteristics including access to capital, ability to geographically expand, and managerial and financial risk sharing may outweigh the negative consequences of loss of control on such factors and pricing. Given that advances in technology have increased the ability to monitor franchisees and social media provides real time assessment of operational performance data, the ability for franchisees to free-ride on brand equity may diminish in certain market segments over time. There are several directions that future research can take to further the understanding of the structure of service triads and business networks in general. We list three areas relevant to the composition, connectivity and characteristics of service triads.

First, future research can explore the implications of various types of service triads. Although service triads are the smallest structure in business networks (Choi and Wu 2009) their compositions are not uniform. For example, in addition to the franchisee owned and operated triads, there are triads composed of the franchisor, a professional management firm contracted by the franchisee who owns the real estate and the customer. This additional layer of outsourcing 
creates new structural links that may impact the relationship between operational and financial performance. Cross-comparisons of various types of service triads will increase the understanding of service triad governance structure.

Second, many research opportunities exist at the connections of service triads. The links between the service provider and the outsourcing company are often many to one (or one to many), creating a network of organizations. For example, a firm could outsource services to a number of agents and in reverse a singular agent could work for several principals, thus resulting in a network of interconnected triads that could influence the behavior of partners. A service provider with multiple contracts with different buying organizations may be more inclined to take advantage of a singular brand given the lowered risks of losing any one contract. Future empirical research should try to expand the investigation. For example, is there a "negative spillover" effect on other franchisees resulting from some franchisee's excessive free-riding on the brand?

Triad relationships are also continually changing due to frequent firm turnover and rebranding. For example, a hotel franchise contract typically has an initial term of 15-20 years with renewal options. The actual duration of the contract depends on the trade-off decisions between stability and flexibility (Eyster and deRoos 2009). Our study offers suggestions on how to manage the structural complexity in franchising systems by leveraging publicly available perception data to monitor operational performance and inform the partner selection and rebranding decisions.

Lastly, examining the potential characteristics of the relationships could provide some insight into potential moderators of free-riding behavior. Transaction cost economics (TCE) (Williamson 1979) and the concept of asset specificity may provide some insight that would help 
enrich our understanding of triadic relationships. Asset specificity, or the degree to which an investment has more value to the relationship than if used for another purpose, may be an important moderator of such free-riding behavior. Hotel assets are relatively fungible across brands and therefore the service provider has the ability to switch brands while maintaining the value of the asset they are invested in. In the case of food service establishments firm specific assets or sunk costs related to trademarking and proprietary production equipment are very high. These firm specific assets can easily account for 70-90\% of the initial costs (Dnes 1993). Additionally, franchisors almost always embed non-compete clauses in their contracts, eliminating the possibility for the franchisee to use the firm specific assets to profit from a similar business (Emerson 1994). Different industries or service relationships have different levels of asset specificity and therefore should be more or less suited to triads where customer service is outsourced. Work incorporating TCE into the service triad framework holds promise.

\section{REFERENCES}

Aaker, David A. 1991. Managing Brand Equity: Capitalizing on the Value of a Brand Name. New York: Free Press.

Adler, Patricia A., and Peter Adler. 1988. "Intense Loyalty in Organizations: A Case Study of College Athletics." Administrative Science Quarterly 33 (3): 401-17.

Apte, Uday M., and Richard O. Mason. 1995. "Global Disaggregation of Information-Intensive Services." Management Science 41 (7): 1250-62.

Balakrishnan, Karthik, Usha Mohan, and Sridhar Seshadri. 2008. "Outsourcing of Front-End Business Processes: Quality, Information, and Customer Contact." Journal of Operations Management 26 (2): 288-302.

Bergen, M., S. Dutta, and O.C. Walker Jr. 1992. "Agency Relationships in Marketing: A Review of the Implications and Applications of Agency and Related Theories." The Journal of Marketing, 1-24.

Berger, Jonah, Alan T Sorensen, and Scott J Rasmussen. 2010. "Positive Effects of Negative Publicity: When Negative Reviews Increase Sales." Marketing Science 29 (5): 815-27.

Berry, Leonard L. 2000. "Cultivating Service Brand Equity." Journal of the Academy of Marketing Science 28 (1): 128-37.

Bickart, Barbara, and Robert M. Schindler. 2001. "Internet Forums as Influential Sources of Consumer Information." Journal of Interactive Marketing 15 (3): 31-40. 
Brickley, James A., and Frederick H. Dark. 1987. "The Choice of Organizational Form: The Case of Franchising." Journal of Financial Economics 18 (2): 401-20.

Brown, James R., Chekitan S. Dev, and Dong-Jin Lee. 2000. "Managing Marketing Channel Opportunism: The Efficacy of Alternative Governance Mechanisms." The Journal of Marketing 64 (2): 51-65.

Caves, Richard E., and William F. Murphy II. 1976. "Franchising: Firms, Markets, and Intangible Assets." Southern Economic Journal 42 (4): 572-86.

Census Bureau, US. 2010. "2007 Economic Census Franchise Report”. US Census Bureau. http://www.census.gov/newsroom/releases/archives/economic_census/cb10-141.html.

Chase, Richard B. 1981. "The Customer Contact Approach to Services: Theoretical Bases and Practical Extensions." Operations Research 29 (4): 698-706.

Chevalier, Judith A., and Dina Mayzlin. 2006. "The Effect of Word of Mouth on Sales: Online Book Reviews." Journal of Marketing Research (JMR) 43 (3): 345-54.

Choi, Thomas Y., and Zhaohui Wu. 2008. "Triads in Supply Networks: Theorizing Buyersupplier-supplier Relationships.” Journal of Supply Chain Management 45 (1): 8-25.

- 2009. "Taking the Leap from Dyads to Triads: Buyer-supplier Relationships in Supply Networks.” Journal of Purchasing and Supply Management 15 (4): 263-66.

Combs, James G, Steven C Michael, and Gary J Castrogiovanni. 2004. "Franchising: A Review and Avenues to Greater Theoretical Diversity." Journal of Management 30 (6): 907-31.

Darr, Eric D, Linda Argote, and Dennis Epple. 1995. "The Acquisition, Transfer, and Depreciation of Knowledge in Service Organizations: Productivity in Franchises." Management Science 41 (11): 1750-62.

Dean, Alison M, and Al Rainnie. 2009. "Frontline Employees' Views on Organizational Factors That Affect the Delivery of Service Quality in Call Centers." Journal of Services Marketing 23: 326-37.

deRoos, Jan A. 2010. "Hotel Management contracts_-Past and Present." Cornell Hospitality Quarterly 51 (1): 68-80.

Dnes, Antony W. 1993. "A Case-Study Analysis of Franchise Contracts." The Journal of Legal Studies 22 (2): 367-93. doi:10.2307/3085586.

Dodds, William B, Kent B Monroe, and Dhruv Grewal. 1991. "Effects of Price, Brand, and Store Information on Buyers' Product Evaluations." Journal of Marketing Research 38 (August): 307-19.

Emerson, Robert W. 1994. "Franchising Covenants Against Competition.” Iowa L. Rev. 80: 1049.

Eyster, J. J., and J. A. deRoos. 2009. The Negotiation and Administration of Hotel Management Contracts. Fourth. Ithaca, NY: Pearson Custom Publishing.

Fayezi, Sajad, Andrew O’Loughlin, and Ambika Zutshi. 2012. “Agency Theory and Supply Chain Management: A Structured Literature Review.” Supply Chain Management: An International Journal 17 (5): 556-70.

Freedman, Matthew, and Renáta Kosová. 2012. "Agency and Compensation: Evidence from the Hotel Industry." Journal of Law, Economics and Organization Forthcoming.

Friedman, Thomas L. 2002. "The World Is Flat: A Brief History of the Twenty-First Century." World 5: 15.

Ghose, Anindya, Panagiotis G. Ipeirotis, and Beibei Li. 2010. "Designing Ranking Systems for Hotels on Travel Search Engines to Enhance User Experience.” In ICIS, edited by Rajiv 
Sabherwal and Mary Sumner, 113. Association for Information Systems. http://dblp.unitrier.de/db/conf/icis/icis2010.html\#GhoseIL10.

Godes, David, and Dina Mayzlin. 2004. "Using Online Conversations to Study Word-of-Mouth Communication.” Marketing Science 23 (4): 545-60.

Handley, Sean M., and W.C. Jr. Benton. 2012. "The Influence of Exchange Hazards and Power on Opportunism in Outsourcing Relationships." Journal of Operations Management 30 (1): 55-68.

Healy, Patrick. 2014. “Ticket Pricing Puts 'Lion King’ Atop Broadway’s Circle of Life.” New York Times, March 17, New York edition, sec. A1.

Heide, Jan B., and George John. 1992. "Do Norms Matter in Marketing Relationships?” The Journal of Marketing 56 (2): 32-44.

Houser, Daniel, and John Wooders. 2006. "Reputation in Auctions: Theory, and Evidence from eBay.” Journal of Economics \& Management Strategy 15 (2): 353-69.

Karmarkar, Uday. 2004. "Will You Survive the Services Revolution?" Harvard Business Review, 100-107.

Klein, Benjamin, and Keith B Leffler. 1981. "The Role of Market Forces in Assuring Contractual Performance." The Journal of Political Economy 89 (4): 615-41.

Krueger, Alan B. 1991. "Ownership, Agency, and Wages: An Examination of Franchising in the Fast Food Industry." The Quarterly Journal of Economics 106 (1): 75-101.

Kuksov, Dmitri, and Ying Xie. 2010. "Pricing, Frills, and Customer Ratings." Marketing Science 29 (5): 925-43.

Lafontaine, Francine. 1999. "Franchising versus Corporate Ownership: The Effect on Price Dispersion." Journal of Business Venturing 14 (1): 17-34.

Lafontaine, Francine, and Kathryn L. Shaw. 2005a. "Targeting Managerial Control: Evidence from Franchising." The Rand Journal of Economics 36 (1): 131-50.

—. 2005b. "Targeting Managerial Control: Evidence from Franchising." RAND Journal of Economics, 131-50.

Li, Mei, and Thomas Y. Choi. 2009. "Triads in Services Outsourcing: Bridge, Bridge Decay and Bridge Transfer." Journal of Supply Chain Management 45 (3): 27-39. General OneFile.

Luca, Michael. 2011. "Reviews, Reputation, and Revenue: The Case of Yelp.com." Working Papers -- Harvard Business School Division of Research, September, 2-39.

Lucking-Reiley, David, Doug Bryan, Naghi Prasad, and Daniel Reeves. 2007. "Pennies from Ebay: The Determinants of Price in Online Auctions*." The Journal of Industrial Economics 55 (2): 223-33.

Luo, Xueming. 2009. "Quantifying the Long-Term Impact of Negative Word of Mouth on Cash Flows and StockPrices." Marketing Science 28 (1): 148-65.

Mathewson, G Frank, and Ralph A Winter. 1985. "The Economics of Franchise Contracts." Journal of Law and Economics 28 (3): 503-26.

Melnik, Mikhail I, and James Alm. 2002a. "Does a Seller's Ecommerce Reputation Matter? Evidence from Ebay Auctions." The Journal of Industrial Economics 50 (3): 337-49. . 2002b. "Does a Seller's Ecommerce Reputation Matter? Evidence from Ebay Auctions." The Journal of Industrial Economics 50 (3): 337-49.

Melnyk, Steven A, Douglas M Stewart, and Morgan Swink. 2004. "Metrics and Performance Measurement in Operations Management: Dealing with the Metrics Maze." Journal of Operations Management 22 (3): 209-18. doi:10.1016/j.jom.2004.01.004. 
Metters, Richard, and Vicente Vargas. 2000. "A Typology of de-Coupling Strategies in Mixed Services.” Journal of Operations Management 18 (6): 663-82.

Michael, Steven C. 2000. "The Effect of Organizational Form on Quality: The Case of Franchising." Journal of Economic Behavior \& Organization 43 (3): 295-318. . 2002. "Can a Franchise Chain Coordinate?" Journal of Business Venturing 17 (4): 32541.

Milgrom, Paul, and John Roberts. 1986. "Price and Advertising Signals of Product Quality." The Journal of Political Economy 94 (4): 796-821.

Morgan, Neil A., Anna Kaleka, and Richard A. Gooner. 2007. "Focal Supplier Opportunism in Supermarket Retailer Category Management." Journal of Operations Management 25 (2): 512-27.

Murray, Keith B. 1991. "A Test of Services Marketing Theory: Consumer Information Acquisition Activities.” Journal of Marketing 55 (1): 10.

Murray, Keith B., and John L. Schlacter. 1990. "The Impact of Services versus Goods on Consumers' Assessment of Perceived Risk and Variability." Journal of the Academy of Marketing Science 18 (1): 51-65.

Niranjan, T.T., and Bhimaraya A Metri. 2008. "Client-Vendor-End User Triad: A Service Quality Model for IS/ITES Outsourcing.” Journal of Services Research 8 (1): 123-38.

O’Reilly III, Charles A., and Jennifer Chatman. 1986. "Organizational Commitment and Psychological Attachment: The Effects of Compliance, Identification, and Internalization on Prosocial Behavior." Journal of Applied Psychology 71 (3): 492-99.

Parasuraman, A., Valarie A. Zeithaml, and Leonard L. Berry. 1985. "A Conceptual Model of Service Quality and Its Implications for Future Research.” Journal of Marketing 49 (4): 41. doi:10.2307/1251430.

Plambeck, Erica L., and Terry A. Taylor. 2005. "Sell the Plant? The Impact of Contract Manufacturing on Innovation, Capacity, and Profitability.” Management Science 51: 133-50.

Quinn, Barry. 1999. "Control and Support in an International Franchise Network." International Marketing Review 16 (4/5): 345-62.

Rao, Akshay R, and Kent B Monroe. 1989. "The Effect of Price, Brand Name, and Store Name on Buyers' Perceptions of Product Quality: An Integrative Review." Journal of Marketing Research, 351-57.

Reichheld, Frederick F. 2001. "Lead for Loyalty.” Harvard Business Review 79 (7): 76.

Ren, Z. Justin, and Yong-Pin Zhou. 2008. "Call Center Outsourcing: Coordinating Staffing Level and Service Quality.” Management Science 54 (2): 369-83.

Resnick, Paul, R. Zeckhauser, J. Swanson, and K. Lockwood. 2006. "The Value of Reputation on eBay: A Controlled Experiment." Experimental Economics 9 (2): 79-101.

Resnick, Paul, and Richard Zeckhauser. 2002. "Trust among Strangers in Internet Transactions: Empirical Analysis of eBay' S Reputation System." Advances in Applied Microeconomics 11 (October): 127-57.

Rossetti, C.L., and T.Y. Choi. 2008. "Supply Management under High Goal Incongruence: An Empirical Examination of Disintermediation in the Aerospace Supply Chain." Decision Sciences 39 (3): 507-40.

Selviaridis, Kostas, and Martin Spring. 2010. "The Dynamics of Business Service Exchanges: Insights from Logistics Outsourcing." Journal of Purchasing and Supply Management 16 (3): 171-84. 
Shane, Scott A. 1998. "Explaining the Distribution of Franchised and Company-Owned Outlets in Franchise Systems.” Journal of Management 24 (6): 717-39.

Standifird, Stephen S. 2001. "Reputation and E-Commerce: eBay Auctions and the Asymmetrical Impact of Positive and Negative Ratings." Journal of Management 27 (3): 279-95.

Stank, Theodore P, Thomas J Goldsby, and Shawnee K Vickery. 1999. "Effect of Service Supplier Performance on Satisfaction and Loyalty of Store Managers in the Fast Food Industry." Journal of Operations Management 17 (4): 429-47. doi:10.1016/S02726963(98)00052-7.

Stewart, Hayden, and David E Davis. 2005. "Price Dispersion and Accessibility: A Case Study of Fast Food." Southern Economic Journal, 784-99.

Tirole, Jean. 1988. The Theory of Industrial Organization: Jean Tirole. MIT press.

Tirunillai, Seshadri, and Gerard J Tellis. 2012. "Does Chatter Really Matter? Dynamics of UserGenerated Content and Stock Performance.” Marketing Science 31 (2): 198-215.

Trusov, Michael, Randolph E Bucklin, and Koen Pauwels. 2009. "Effects of Word-of-Mouth Versus Traditional Marketing: Findings from an Internet Social Networking Site." Journal of Marketing 73 (5): 90-102.

Van der Valk, Wendy, and Jos van Iwaarden. 2011. "Monitoring in Service Triads Consisting of Buyers, Subcontractors and End Customers." Special Issue of Best Papers of the 19th Annual IPSERA Conference 201017 (3): 198-206.

Van der Valk, Wendy, Finn Wynstra, and Björn Axelsson. 2009. "Effective Buyer-Supplier Interaction Patterns in Ongoing Service Exchange." International Journal of Operations \& Production Management 29 (8): 807-33.

Villanueva, Julian, Shijin Yoo, and Dominique M Hanssens. 2008. "The Impact of MarketingInduced Versus Word-of-Mouth Customer Acquisition on Customer Equity Growth.” Journal of Marketing Research (JMR) 45 (1): 48-59.

Williamson, Oliver E. 1979. "Transaction-Cost Economics: The Governance of Contractual Relations." The Journal of Law and Economics 22 (2): 233.

Wynstra, Finn, Björn Axelsson, and Wendy van der Valk. 2006. "An Application-Based Classification to Understand Buyer-Supplier Interaction in Business Services." International Journal of Service Industry Management 17 (5): 474-96.

Zhu, Feng, and Xiaoquan (Michael) Zhang. 2010. "Impact of Online Consumer Reviews on Sales: The Moderating Role of Product and Consumer Characteristics." Journal of Marketing 74 (2): 133-48.

Zsidisin, G.A., and L.M. Ellram. 2003. "An Agency Theory Investigation of Supply Risk Management." Journal of Supply Chain Management 39 (3): 15-27.

${ }^{\mathrm{i}}$ RevPAR (Revenue Per Available Room) is the total guest room revenue divided by the total number of available rooms. RevPAR differs from ADR because RevPAR is affected by the 
amount of unoccupied available rooms, while ADR shows only the average rate of rooms actually sold. RevPAR and ADR are key performance indicators in the hotel industry. ${ }^{i i}$ Other combinations of ownership, management and chain affiliation also exist but excluded from our current study due to irrelevance to our focus on triadic relationship.

iii A competitive set consists of a group of hotels by which a property can compare itself to the group's aggregate performance. There must be a minimum of three hotels in any competitive set and a minimum of four hotels in Europe, excluding the subject hotel. To protect proprietary data, a single hotel or brand cannot exceed $40 \%$ of the competitive set for North American hotels and $50 \%$ for hotels outside of North America. A single hotel company (i.e. Marriott brands, Choice brands, etc.) may only comprise 60 percent of the competitive set room supply. Source: http://www.strglobal.com/documents/Definitions.pdf.

${ }^{\text {iv }}$ ADR (Average Daily Rate) is a measure of the average rate paid for rooms sold, calculated by dividing room revenue by rooms sold. We use ADR Index, which measures a hotel's ADR performance relative to an aggregated grouping of hotels (e.g. competitive set, market, submarket/tract). Adapted from: http://www.strglobal.com/documents/Definitions.pdf.

${ }^{v}$ More details on the Global Review Index can be found at http://www.reviewpro.com/product/global-review-index. 